\title{
Chemical Composition and Antibacterial Activity of Aloysia triphylla (L'Hérit) Britton Extracts Obtained by Pressurized $\mathrm{CO}_{2}$ Extraction
}

\author{
Thaylise Vey Parodi ${ }^{1}$, Agueda Palmira de Castagna Vargas $^{2}$, Carina Krewer ${ }^{2}$, Érico \\ Marlon de Moraes Flores $^{3}$, Bernardo Baldisserotto ${ }^{1}$, Berta Maria Heinzmann ${ }^{4 *}$, José \\ Vladimir de Oliveira ${ }^{5}$, Ariana Secco Popiolski ${ }^{5}$ and Mariane Minozzo ${ }^{5}$ \\ ${ }^{I}$ Departamento de Fisiologia e Farmacologia; ${ }^{2}$ Departamento Medicina Veterinária Preventiva; ${ }^{3}$ Departamento de \\ Química; ${ }^{4}$ Departamento de Farmácia Industrial; Universidade Federal de Santa Maria; 97105-900; Santa Maria \\ - RS - Brasil. ${ }^{5}$ Departamento de Engenharia de Alimentos; URI; Av. Sete de Setembro, 1621; 97700-000; Erechim \\ - RS-Brasil
}

\begin{abstract}
This study investigated the chemical composition of five different extracts of Aloysia triphylla and their activity against Aeromonas sp. The extracts were obtained from the dried leaves by pressurized $\mathrm{CO}_{2}$ extraction at 30 , 50 and $70^{\circ} \mathrm{C}$, and 100, 150, and 200 bar, and analyzed by GC/FID and GC-MS. The antibacterial activity was assayed by the microdilution method. The tested microorganisms comprised seven Aeromonas isolates obtained from the kidney of infected silver catfish, Rhamdia quelen. The yield, chemical composition and antibacterial activity of the extracts were dependent on the extraction conditions. Mono and sesquiterpenoids were the major constituents of all the extracts and the highest extraction yield was obtained at $70^{\circ} \mathrm{C}$ and 200 bar. A. triphylla presented moderate antibacterial activity against Aeromonas sp.
\end{abstract}

Key words: Aloysia triphylla, pressurized carbon dioxide extraction, Aeromonas sp.

\section{INTRODUCTION}

Aloysia triphylla (L’Herit.) Britton [syn. Aloysia citriodora Palau, Lippia citriodora (Ort.) HBK, Verbenaceae] is cultivated mainly due to the lemon-like scent emitted from its leaves and is utilized for the preparation of herbal tea (Argyropoulou et al. 2007) which is known to have antispasmodic, antipyretic, sedative, and digestive activity (Carnat et al. 1999; Valentão et al. 1999; Pascual et al. 2001; Gomes et al. 2005), antimicrobial activity (Oskay et al. 2005) and antioxidant properties (Pereira et al. 2007). This plant has a long history of folk use to treat asthma, spasms, cold, fever, flatulence, colic, diarrhea, indigestion, insomnia, and anxiety (Carnat et al. 1999; Pascual et al. 2001; Gomes et al. 2005). The supply of Aloysia triphylla is from the Mediterranean countries such as Morocco, Portugal, Italy, and France, as well as Southeastern Asian countries. Some Latin American countries such as Chile, Columbia, Uruguay and Brazil also produce and supply the leaves of A. triphylla (Bandoni et al. 2008).

The conventional processes for extracting the terpenoids such as hydrodistillation and solvent extraction are usually inferior to supercritical fluid extraction (SFE), mainly regarding selectivity. It is

*Author for correspondence: berta.heinzmann@gmail.com 
well known that the SFE process makes use of mild temperatures, which avoids the degradation of thermo-sensitive compounds, and the low water content limits hydrolytic processes (Crabas et al. 2003; Wenqiang et al. 2007). This extraction method offers many important advantages over the hydrodistillation such as low energy cost and the possibility of extraction optimization by changing the processing parameters such as temperature, content of modifier (co-solvent), dynamic extraction time and fine tuning the extraction pressure (Khajeh et al. 2004). Moreover, the use of carbon dioxide brings the additional advantages of being non-flammable, fairly non-toxic, costeffective, easily removed from the extract following decompression (Scalia et al. 1999) and, to a certain extent, solubilizes the lipophilic substances (Sahena et al. 2009).

The genus Aeromonas comprises a group of Gramnegative, facultative anaerobic bacteria that are pathogenic to aquatic and terrestrial animals and have also been associated with a wide spectrum of infectious diseases in humans and animals (Paniagua et al. 1999; Krzyminska et al. 2009). The widespread distribution of Aeromonas species in the aquatic environment combined with the stress induced by intensive culture practices predisposes fish to infections (Saavedra et al. 2004). Aeromonas infection is a significant concern in aquaculture as it is often associated with high mortality and morbidity rates (Clermont et al. 2008).

In this context, the aim of this work was to investigate the influence of temperature and pressure on the extraction yield and chemical composition of the extracts obtained by the pressurized fluid extraction of $A$. triphylla leaves. In order to determine the best parameters for plant material extraction in terms of activity optimization, the antibacterial activity of the extracts against Aeromonas sp was also evaluated.

\section{MATERIALS AND METHODS}

The leaves of Aloysia triphylla were purchased from the local market of Santa Maria (RS, Brazil) and identified by Dr. Gilberto Dolejal Zanetti (Department of Industrial Pharmacy, UFSM). A voucher specimen (SMDB No. 11169) was deposited in the herbarium of the Department of Biology, UFSM. Leaves were dried at $40^{\circ} \mathrm{C}$ in a ventilated drying oven and subsequently powdered in a knife mill, homogenized and the particles classified in a sieve (Taylor series), excluding the particles smaller than 200 mesh, then stored in light-protected plastic bags at $-4^{\circ} \mathrm{C}$ in a domestic freezer.

The experiments were performed in a laboratory scale unit (Mazutti et al. 2006). Basically, it consisted of of a $\mathrm{CO}_{2}(99.9 \%$ purity, purchased from White Martins) reservoir, two thermostatic baths, a syringe pump (ISCO 260D), a $0.1 \mathrm{dm}^{3}$ jacketed extraction vessel, an absolute pressure transducer (Smar, LD301) equipped with a portable programmer (Smar, HT 201) with a precision of \pm 0.12 bar, a collector vessel with a glass tube and a cold trap. About $25 \mathrm{~g}$ of dried and powdered leaves of A triphylla were loaded into the extraction vessel. The $\mathrm{CO}_{2}$ was pumped into the bed at a constant flow rate of $2 \mathrm{~g} \mathrm{~min}^{-1}$, which was supported by two 300 mesh wire disks at both ends, and was kept in contact with the herbaceous matrix for at least one hour to allow the system to stabilize. Afterwards, the extract was collected by opening the micrometering valve and the $\mathrm{CO}_{2}$ mass flow was recorded by the pump recordings. Then the extract was weighed, the glass tube was re-connected to the equipment, and this procedure was repeated until no significant mass was extracted. The extraction was completed within approximately $120 \mathrm{~min}$, isothermally at desired pressure and temperature. An experimental factorial design using three temperatures $(30,50$ and $\left.70^{\circ} \mathrm{C}\right)$ and three pressure levels $(100,150$ and 200 bar) was established so as to assess the influence of process variables on the extraction yield, extract composition and antimicrobial activity.

GC-FID and TIC analysis was performed on a Varian gas chromatograph (Model CP-3800) equipped with mass detector Saturno using a capillary column fused silica VF-5 MS (Varian) (30 m x $0.25 \mathrm{~mm} \times 0.25 \mu \mathrm{m})$. The conditions of analysis included: injector 1177 (MS), $250^{\circ} \mathrm{C}$, split 1:20 (FID and MS); injetor 1093 (FID), $250^{\circ} \mathrm{C}$. The flow of the carrier gas (He) was $1 \mathrm{~mL} / \mathrm{min}$ (both FID and MS). The column oven temperature was initially kept at $50^{\circ} \mathrm{C}$ for $4 \mathrm{~min}$ and then heated up to $280^{\circ} \mathrm{C}$ (increasing rate $4^{\circ} \mathrm{C} / \mathrm{min}$ ). Injection volume was $1 \mu \mathrm{L}$ and the detector temperatures were $200^{\circ} \mathrm{C}$ (MS) and $310^{\circ} \mathrm{C}$ (FID). The GC-MS analysis was performed with eletronionization $(70 \mathrm{eV})$.

The constituents of the extracts were identified based on the retention index (RI) determined by 
using a calibration curve of a homologous series of n-alkanes $\left(\mathrm{C}_{8}-\mathrm{C}_{32}\right)$ injected under the same chromatographic conditions of the samples and fragmentation models of mass spectra. Both data were compared with the literature (Adams, 2001) and with the equipment's library (NIST, 1998). The quantitative data were obtained from the FID eletronic integration peak areas.

The tested microorganisms comprised seven Aeromonas sp. isolates obtained from the kidney of infected silver catfish, R. quelen. The isolates were phenotypically identified by the conventional methods to genus according to Quinn et al. (1994). Inoculum suspensions were prepared as described in CLSI M7-A6 protocol (NCCLS, 2003) by diluting the scraped cell mass in $0.85 \% \mathrm{NaCl}$ solution adjusted up to 0.5 in the McFarland scale and confirmed by spectrophotometrical reading at $580 \mathrm{~nm}$. The cell suspensions were finally diluted to $5 \times 10^{4} \mathrm{UFC} \mathrm{mL}^{-1}$ to be used in the activity assays in microdilution plates, where each hole contained $200 \mu \mathrm{L}$ Mueller-Hinton broth and different concentrations of the test extracts. Mueller-Hinton broth, methanol and bacterial inoculum were used as negative control. For positive control, Mueller-Hinton broth and bacterial inoculum were added. The plates were incubated at $37^{\circ} \mathrm{C}$ for $24 \mathrm{~h}$.

The different extracts were dissolved in methanol at the ratio of 1:2. The final extracts concentrations in the plates were: $25000 ; 12500 ; 6250 ; 3125$; $1562.5 ; 781.25 ; 390.62 ; 195.31 \mu \mathrm{g} \mathrm{mL}^{-1}$. The tests were performed in duplicate. After the incubation period, all the plates containing Mueller-Hinton broth were replicated and incubated at $37^{\circ} \mathrm{C}$ for $24 \mathrm{~h}$ to evaluate the Minimum Bactericidal Concentration (MBC). Minimum Inhibitory Concentrations (MIC) were not determined due the difficulty of solubilizing the extract in the broth.

Data are reported as the mean values \pm standard deviations $(\sigma)$. The homogeneity of variances among the groups was tested with the Levene test. As the data did not present homogeneous variances, groups were compared by KruskalWallis test, followed by Mann-Whitney post hoc tests. All the tests were performed with Statistica 5.1 (1997; StatSoft Inc., Tulsa, OK, USA). The minimum significance level was set at $p<0.05$.

\section{RESULTS AND DISCUSSION}

The semisolid extracts obtained by the pressurized $\mathrm{CO}_{2}$ extraction were light or dark yellow in color, similar to the extracts of Ocimum basilicum L. obtained by the supercritical carbon dioxide extraction (Lachowicz et al. 1997). Figure 1 shows the extraction kinetics for all the experimental conditions. As commonly found for SFE of vegetable matrices, extraction kinetic curves were characterized by a linear portion followed by the decreasing and nearly zero extraction rates (Fig. 1). The cumulative yield of the extracts increased up to $100-120 \mathrm{~min}$, except at $70^{\circ} \mathrm{C}$ and $100 \mathrm{bar}$. As seen from Table 1, the yield at this experimental condition was significantly lower than those obtained under the other experimental conditions. Here, the extraction yield is defined as the weight percentage of the extract in relation to the initial load of the raw material in the extractor (Table 1). According to Table 1 and Figure 1, the highest extraction yield was obtained at $70^{\circ} \mathrm{C}$ and 200 bar, thus corroborating the positive influence of higher system pressures.

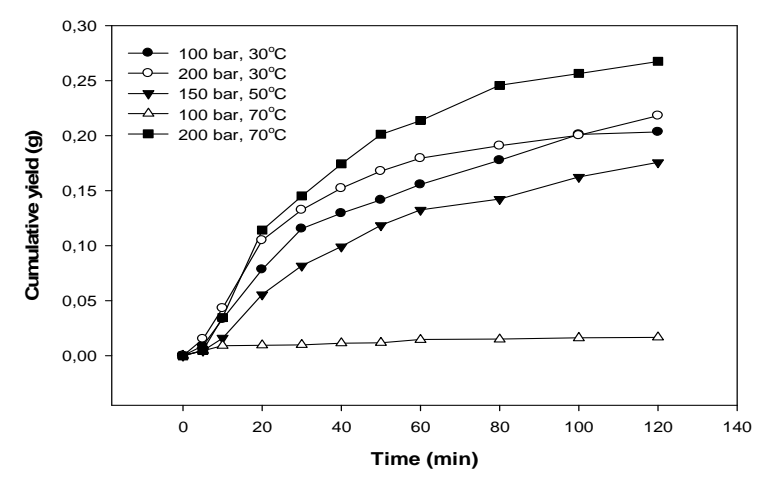

Figure 1 - Relationship between cumulative yields of the extracts obtained from leaves of Aloysia triphylla by supercritical fluid at different temperatures and pressures. 
Table 1 - Extraction yield and antimicrobial activity against Aeromonas sp. of the supercritical fluid extracts obtained from leaves of Aloysia triphylla.

\begin{tabular}{cccc}
\hline Temperature $\left({ }^{\mathbf{0}} \mathbf{C}\right)$ & Pressure $($ bar $)$ & Yield $^{*} \pm \sigma(\mathbf{w t} \%)$ & Minimum bactericidal concentration $\left(\boldsymbol{\mu g} \mathbf{~ m L}^{-1}\right)$ \\
\hline 30 & 100 & $0.8 \pm 0.007^{\mathrm{A}}$ & $1339.0^{\mathrm{A}}$ \\
70 & 100 & $0.07 \pm 0.002^{\mathrm{B}}$ & $4464.0^{\mathrm{B}}$ \\
50 & 150 & $0.73 \pm 0.04^{\mathrm{A}}$ & $3125.0^{\mathrm{C}}$ \\
30 & 200 & $0.91 \pm 0.05^{\mathrm{A}}$ & $1674.0^{\mathrm{AC}}$ \\
70 & 200 & $1.13 \pm 0.03^{\mathrm{C}}$ & $1562.0^{\mathrm{AC}}$ \\
\hline
\end{tabular}

Means identified by different capital letters in columns were significantly different $(\mathrm{p}<0.05)$ as determined by Kruskal-Wallis and MannWhitney tests. * mean $\pm \sigma, \mathrm{n}=2$

These cause an enhancement of solvent power, and system temperature, affecting the vapor pressure of the solute to be extracted (Khajeh et al. 2004). This result was in agreement with the best extraction yield obtained by the supercritical $\mathrm{CO}_{2}$ extraction of $O$. basilicum L., in which the highest yield was obtained at the highest temperature $\left(50^{\circ} \mathrm{C}\right)$ and pressure (250 bar) (Mazutti et al. 2006). In the present study, at the highest temperature chosen, $70^{\circ} \mathrm{C}$, the pressure was really determinant for the extraction yield. Hence, the extract obtained at 100 bar showed the smallest yield, while the extract obtained at 200 bar presented the highest cumulative yield.

It is well known that supercritical fluid extraction recovery and selectivity depends greatly on the balance between the fluid density and solute vapor pressure. For instance, the extracts obtained at $30^{\circ} \mathrm{C}$ and 100 bar (Table 2), $30^{\circ} \mathrm{C}$ and 200 bar (Table 3 ), $50^{\circ} \mathrm{C}$ and 150 bar (Table 4 ), and $70^{\circ} \mathrm{C}$ and 200 bar (Table 5) contained mainly monoterpenoids $\left(\mathrm{C}_{10}\right.$ compounds), which are lipophilic compounds with low molecular weight, followed by sesquiterpenoids ( $\mathrm{C}_{15}$ compounds).

Table 2 - Chemical composition of major compounds present in the supercritical fluid extracts from leaves of $A$. triphylla obtained at $30^{\circ} \mathrm{C}$ and 100 bar.

\begin{tabular}{|c|c|c|c|c|}
\hline Compound & RT & $\mathbf{R C}$ & RTIR & $\%$ \\
\hline Limonene & 9.532 & 1036 & 1029 & 0.7 \\
\hline Tagetone & 10.045 & 1052 & 1053 & 1.5 \\
\hline Linalool & 11.577 & 1098 & 1097 & 1.2 \\
\hline Z-Citral & 16.566 & 1244 & 1238 & 13.6 \\
\hline$E$-Citral & 17.590 & 1363 & 1362 & 19.3 \\
\hline Z-Citral dimethoxy & 19.106 & 1320 & 1318 & 0.8 \\
\hline Citronellyl acetate & 20.055 & 1349 & 1353 & 2.5 \\
\hline Neryl acetate & 20.463 & 1362 & 1362 & 0.9 \\
\hline Geranyl acetate & 21.105 & 1381 & 1381 & 3.1 \\
\hline Total of monoterpenoids & & & & 43.6 \\
\hline$E$ - $\beta$-Caryophyllene & 22.462 & 1424 & 1427 & 5.6 \\
\hline$\alpha$-Curcumene & 24.363 & 1485 & 1481 & 11.0 \\
\hline$\gamma$-Cadinene & 25.383 & 1519 & 1514 & 1.2 \\
\hline$\alpha$-cadinene & 26.086 & 1543 & 1539 & 0.8 \\
\hline Z-Muurol-5-en- $4-\beta$-ol & 26.502 & 1557 & 1552 & 1.2 \\
\hline Caryophyllene oxide & 27.470 & 1590 & 1581 & 14.3 \\
\hline 9-epi-E-Caryophyllene-14-ol & 29.732 & 1671 & 1670 & 0.7 \\
\hline Caryophyllene acetate & 30.338 & 1692 & 1701 & 1.9 \\
\hline Acorenone B & 30.553 & 1700 & 1698 & 1.5 \\
\hline $2 E, 6 E$ Farnesyl acetate & 34.152 & 1837 & 1847 & 2.1 \\
\hline $8 S$-13-Cedranediol & 35.247 & 1881 & 1880 & 2.1 \\
\hline Total of sesquiterpenoids & & & & 42.4 \\
\hline n-Octanol & 10.236 & 1058 & 1068 & 0.7 \\
\hline Methyl butyl 2-methyl butanoate & 11.773 & 1104 & 1100 & 0.7 \\
\hline Cinerolone & 22.188 & 1415 & 1426 & 1.0 \\
\hline \multicolumn{4}{|c|}{ Total of constituents with no terpenoid structure } & 2.4 \\
\hline \multicolumn{4}{|c|}{ Total percentage of identified components } & 88.4 \\
\hline
\end{tabular}


Table 3 - Chemical composition of major compounds in the supercritical fluid extracts from leaves of A. triphylla obtained at $30^{\circ} \mathrm{C}$ and 200 bar.

\begin{tabular}{|c|c|c|c|c|}
\hline Compound & RT & $\mathbf{R C}$ & RTIR & $\%$ \\
\hline Limonene & 9.336 & 1031 & 1029 & 86.0 \\
\hline Total of monoterpenoids & & & & 86.0 \\
\hline Total percentage of identified & & & & 86.0 \\
\hline
\end{tabular}

Table 4 - Chemical composition of major compounds present in the supercritical fluid extracts from leaves of $A$. triphylla obtained at $50^{\circ} \mathrm{C}$ and 150 bar.

\begin{tabular}{|c|c|c|c|c|}
\hline Compound & RT & RC & RTIR & $\%$ \\
\hline Z-Citral & 16.545 & 1244 & 1238 & 12.6 \\
\hline E-Citral & 17.571 & 1274 & 1282 & 16.3 \\
\hline Geranyl acetate & 21.091 & 1381 & 1380 & 2.7 \\
\hline Total of monoterpenoids & & & & 29.1 \\
\hline$\beta$-Caryophyllene & 22.436 & 1424 & 1418 & 6.5 \\
\hline$\alpha$-Caryophyllene & 23.580 & 1460 & 1451 & 1.8 \\
\hline Aromadendrene & 23.709 & 1464 & 1460 & 0.9 \\
\hline Germacrene D & 24.163 & 1479 & 1474 & 2.4 \\
\hline$\alpha$-Curcumene & 24.340 & 1484 & 1481 & 1.2 \\
\hline$\tau$-Elemene & 24.810 & 1500 & 1482 & 1.8 \\
\hline$\beta$-Himachalene & 25.179 & 1512 & 1494 & 1.1 \\
\hline$\tau$-Cadinene & 25.357 & 1518 & 1514 & 0.8 \\
\hline$\beta$-Cadinene & 25.483 & 1522 & 1519 & 0.9 \\
\hline$\alpha$-Muurolene & 26.060 & 1542 & 1537 & 1.6 \\
\hline Isoaromadendrene epoxide & 27.248 & 1582 & 1579 & 1.0 \\
\hline Total of sesquiterpenoids & & & & 26.0 \\
\hline Squalene & 54.399 & 2929 & 2914 & 11.4 \\
\hline Total of triterpenoids & & & & 11.4 \\
\hline Octadecyne & 34.133 & 1836 & 1828 & 3.0 \\
\hline 2-Methyl-7-octadecyne & 35.255 & 1881 & 1863 & 1.4 \\
\hline Linoleic acid, ethyl ester & 41.976 & 2169 & 2166 & 2.1 \\
\hline Heptacosanol & 57.088 & 2938 & 2948 & 9.5 \\
\hline \multicolumn{2}{|c|}{ Total of constituents with no terpenoid structure } & & & 16.0 \\
\hline \multicolumn{2}{|c|}{ Total percentage of identified components } & & & 82.5 \\
\hline
\end{tabular}

Both groups are the main constituents of the most essential oils and are easily extracted by hydrodistillation, as they are generally volatile. In the extracts obtained at 100 bar and $30^{\circ} \mathrm{C}$ (Table 2), 150 bar and $50^{\circ} \mathrm{C}$ (Table 4), and 200 bar and $70^{\circ} \mathrm{C}$ (Table 5), the monoterpenoid citral were the major component, while in the extract obtained at 200 bar and $30^{\circ} \mathrm{C}$ (Table 3), only one constituent, the monoterpenoid limonene was detected. Limonene has been extensively investigated due its application in the flavor and fragrance industries (Erasto and Viljoen 2008) as well as its medicinal potential (Bakkali et al. 2008; Yoon et al. 2010). However, the extract obtained at $70^{\circ} \mathrm{C}$ and 100 bar (Table 6) showed the presence of high amount of caryophyllene oxide, a compound with sesquiterpenoid structure which has been considered to be an artifact produced during the distillation as a consequence of the relatively high temperatures involved (Silva et al. 2010). Sköld et al. (2006) also described the oxidation of caryophyllene when exposed to air, yielding the corresponding oxide. However, their findings did not explain the fact that only one extract contained large amounts of caryophyllene oxide, since the entire plant material was processed in the same way prior to extraction. There was no report in the literature about this compound as an artifact during the supercritical fluid extraction process. However, caryophyllene, which has been considered its precursor, was detected in three of the five extracts obtained (see Tables 2, 4, and 5).

As regards the number of constituents detected by GC, the extract obtained at $70^{\circ} \mathrm{C}$ and 200 bar was the richest one, with 29 different compounds (Table 5), followed by the extracts obtained at $50^{\circ} \mathrm{C}$ and 150 bar (27 compounds, Table 4), and at $30^{\circ} \mathrm{C}$ and 100 bar (23 compounds, Table 2). 
However, for the extracts obtained at $30^{\circ} \mathrm{C}$ and 200 bar and $70^{\circ} \mathrm{C}$ and 100 bar, only one constituent was detected, limonene and caryophyllene oxide, respectively (Tables 3 and $6)$.

Table 5 - Chemical composition of major compounds present in the supercritical fluid extracts from leaves of $A$. triphylla obtained at $70^{\circ} \mathrm{C}$ and 200 bar.

\begin{tabular}{|c|c|c|c|c|c|}
\hline Compound & RT & $\mathrm{RC}$ & RTIR & $\%$ & \\
\hline Limonene & 9.336 & 1031 & 1029 & 2.0 & \\
\hline$p$-Mentha-triene & 9.675 & 1071 & 1085 & 0.5 & \\
\hline Z-Citral & 16.572 & 1244 & 1238 & 15.3 & \\
\hline E-Citral & 17.605 & 1275 & 1282 & 17.8 & \\
\hline$\alpha$-Cubebene & 21.024 & 1349 & 1345 & 0.8 & \\
\hline Geranyl acetate & 21.121 & 1382 & 1381 & & 2.5 \\
\hline Total of monoterpenoids & & & & & 38.9 \\
\hline$\alpha$-Caryophyllene & 23.586 & 1457 & 1466 & & 1.2 \\
\hline (-)-allo Aromadendrene & 23.713 & 1464 & 1460 & & 1.0 \\
\hline Germacrene D & 24.189 & 1479 & 1474 & & 3.0 \\
\hline$\alpha$-Curcumene & 24.367 & 1483 & 1481 & & 2.0 \\
\hline$\tau$-Elemene & 24.827 & 1500 & 1482 & & 2.8 \\
\hline$\beta$-Himachalene & 24.954 & 1504 & 1494 & & 5.5 \\
\hline$\gamma$-Cadinene & 25.370 & 1518 & 1514 & & 6.1 \\
\hline (-) $\beta$-Cadinene & 25.497 & 1523 & 1519 & & 2.2 \\
\hline$\alpha$-Muurolene & 26.063 & 1542 & 1537 & & 1.2 \\
\hline Caryophyllene oxide & 26.607 & 1561 & 1581 & & 5.3 \\
\hline Hexahydro farnesyl acetone & 34.351 & 1845 & 1833 & & 2.4 \\
\hline Total of sesquiterpenoids & & & & & 32.7 \\
\hline 3-Octadecyne & 34.143 & 1837 & 1828 & & 9.7 \\
\hline $\begin{array}{l}(9,12) \text { - Hexadecadienoic acid } \\
\text { methyl ester }\end{array}$ & 35.246 & 1880 & 1894 & & 3.0 \\
\hline \multicolumn{5}{|c|}{ Total of constituents with no terpenoid structure } & 12.7 \\
\hline \multicolumn{5}{|c|}{ Total percentage of identified components } & 84.3 \\
\hline
\end{tabular}

Table 6 - Chemical composition of major compounds present in the supercritical fluid extracts from leaves of $A$. triphylla obtained at $70^{\circ} \mathrm{C}$ and 100 bar.

\begin{tabular}{lcccc}
\hline Compound & RT & RC & RTIR & \% \\
\hline Caryophyllene oxide & 27.446 & 1590 & 1585 & 88.0 \\
\hline Total of sesquiterpenoids & & & 88.0 \\
\hline Total percentage of identified components & & & 88.0
\end{tabular}

$\mathrm{RT}=$ retention time; $\mathrm{RC}=$ retention index calculated $\mathrm{RTIR}=$ retention index reference; $\%$ = relative percentage

The chemical composition varied according to the experimental conditions, but some similarities could be observed. A predominance of compounds with terpenoid structure was observed in all the extracts. Monoterpenoids were the major components in almost all the extracts and were absent only in the extract obtained at $70^{\circ} \mathrm{C}$ and 100 bar (Table 6). Only the extract obtained at $50^{\circ} \mathrm{C}$ and 150 bar contained squalene, a precursor of triterpenoids and steroids in the biosynthetic pathway of plants (Table 4).

It was also possible to obtain the compounds with a non-terpenoidic structure and a high molecular weight, which seemed to be influenced by the temperature and pressure since different structures were obtained at different extraction conditions (Tables 2, 4 and 5). The same method of extraction also presented variations in the extraction of compounds of high molecular weight from Tanacetum cinerariifolium when using different temperatures and pressures (Marongiu et al. 2009). In a general sense, this work showed that it was possible to select the most favorable conditions for the extraction of different terpene groups present in the leaves of A. triphylla. The qualitative and quantitative differences observed indicated that the main constituents of the extract could then be 
chosen by adjusting the operating parameters such as pressure and temperature.

Three of the extracts from the leaves of $A$. triphylla (those obtained at 100 bar and $30^{\circ} \mathrm{C}$ and at $200 \mathrm{bar}$ and $30^{\circ} \mathrm{C}$ and $70^{\circ} \mathrm{C}$ ) showed activity against Aeromonas sp (Table 1). Antibacterial activity against another genus of Gram-negative bacterium (Escherichia coli) was previously described for the ethanolic extract of A. triphylla (Oskay et al. 2005). The essential oil of this species also presented antibacterial activity against four Gram-negative clinical isolates from the urinary tract infections (Rojas et al. 2010).

The MBC values of the obtained extracts did not differ statistically among themselves, nevertheless differences appeared with regard to the extracts obtained at $50^{\circ} \mathrm{C}$ and $150 \mathrm{bar}$ and also at $70^{\circ} \mathrm{C}$ and 100 bar (Table 1), which showed a weaker antibacterial activity. Probably this activity was due to the synergistic action of several components because most of them were present in small percentages. The present study did not analyze the antibacterial activity of the isolated substances from the extracts. However, considering the chemical class of the major components of each extract, it was observed that the extract with the weakest antibacterial activity was the only one, which did not have the monoterpenoids in its composition. This result, obtained for the extract produced at $70^{\circ} \mathrm{C}$ and $100 \mathrm{bar}$, indicated that the monoterpenoids were probably important for the antimicrobial activity of A. triphylla leaves extracts against Aeromonas sp. The caryophyllene oxide, which was identified as the major compound of this extract (Table 6), lacked the antimicrobial activity against yeasts, Grampositive and Gram-negative bacteria at concentrations up to $1716 \mu \mathrm{g} / \mathrm{mL}$ (Silva et al. 2010). On the other hand, monoterpenoids are recognized as food preservatives due their antimicrobial activity (Singh et al. 2010).

The tolerance of Gram-negative bacteria such as Pseudomonas aeruginosa for monoterpene constituents in consequence of their outer membrane has been reported in the literature (Mann et al. 2000). This could be explained by the presence of a hydrophilic membrane in the outer portion of Gram-negative bacterial cell wall that blocks the penetration of hydrophobic substances (Ozturk and Ercisli 2006), such as terpene constituents that are part of the chemical composition of essential oils (Ceylan and Fung 2004) and were present in the extracts obtained by the supercritical fluid extraction as described in this work. This obstacle imposed by the Gramnegative bacteria could have reduced the antimicrobial activity of the substances reported for this purpose such as limonene (Ozturk and Ercisli 2006) and citral (Kim et al. 1995; Fisher and Phillips 2006). Although Gram-negative bacteria are usually more resistant to plant-origin antimicrobials, Aeromonas hydrophila has been described as the most sensitive one (Tajkarimi et al. 2010).

The essential oil of A. triphylla showed antibacterial activity against different strains (Staphylococcus aureus, Enterococcus faecalis, Escherichia coli, Klebsiella pneumoniae) observing inhibition zones with diameters between 7 and $19 \mathrm{~mm}$ and MIC values between 10 and 60 $\mathrm{mg} / \mathrm{mL}$, without activity against Pseudomonas aeruginosa (Rojas et al. 2010). There was no activity of the oil of A. triphylla obtained by hydrodistillation of the aerial parts of the plant against $P$. aeruginosa. The antimicrobial activity against genito-urinary Gram-positive pathogens such as $S$. aureus (MIC $\geq 18.75 \mathrm{~mm}$ ) and $E$. faecalis (MIC $\geq 17.75 \mathrm{~mm}$ ) has also been observed for the essential oil of A. triphylla (Rojas et al. 2010).

Although it was not possible to assign the activity against Aeromonas sp to a component in particular, oxygenated monoterpens such as citral which were present as a major component in three of the obtained extracts, showed inhibitory effect against Gram-negative and Gram-positive (Kim et al. 1997) microorganisms and antibacterial activity (Kim et al. 1995; Fisher and Philips 2006; Tajkarimi et al. 2010). Some monoterpenoids such as citral have been tested as preservatives in fishbased food products in order to reduce the contamination and to increase the useful life of these foods (Svodoba and Greenaway 2003; Burt 2004). Limonene also showed antimicrobial activity against the food-borne pathogens, fungi and resistant strains of Gram-positive and Gramnegative bacteria (Singh et al. 2010; Tajkarimi et al. 2010). Citral and limonene have been recognized by the regulatory agencies in the US and EU as safe for the use as food additive (Tajkarimi et al. 2010).

There are no reports regarding the antimicrobial activity of the non-terpene compounds found (Tables 2, 4 and 5). This is probably because the plants that present the terpenoids as secondary metabolites are generally superior in antimicrobial 
activity. However, the strength of this activity depends on external factors (Geiyd et al. 2005), including the agronomic practices and methodology of extraction, which would alter the chemical composition of the extracts and consequently influence their antimicrobial activity (Delaquis et al. 2002).

In general, the antimicrobial effect of essential oil is attributed to the $\mathrm{C}_{10}$ and $\mathrm{C}_{15}$ carbon terpenes with specific structural characteristics (Dorman and Deans 2000). Some of these terpene structures alone are bioactive and can interfere with the physical parameters of microorganisms such as absorption and bioavailability (Svodoba et al. 2006). The interaction between these terpenoid structures and microbes, which ultimately induces the antimicrobial activity is not well understood. The inhibitory effect of such molecules as citral and limonene (Svodoba and Greenway 2003) is generally explained by their interaction with the bacterial cell structural components (Belletti et al., 2004) like the phospholipid bilayer of the cell membrane, causing increase of permeability and leakage of intracellular constituents that are of vital importance for the bacteria (Singh et al. 2002). Some monoterpene alcohols can lead to inhibition of oxygen consumption, respiratory electron flow and oxidative phosphorylation of the microorganism (Reichling et al. 2009). Terpenes can also transpose the bacterial membrane, causing cell swelling, dissipation of $\mathrm{pH}$ gradients and electric potential (Sikkema et al. 1994).

However, when extracts are applied in a concentrated form as in the present study, the delivery of these hydrophobic compounds to bacterial cells may be reduced. An uneven distribution and accessibility of terpenes to bacterial cells may be one of the reasons for the relatively low bactericidal activity (Inouye et al. 2001), where the insolubility of the constituents in the culture medium may change the effectiveness of the extract besides chemical composition of plant material. Romeo et al. (2008) showed the antimicrobial efficacy of essential oil of $A$. triphylla in an experiment using a liquid medium. However, other essential oils in the same medium were less effective. Besides the differences in the chemical composition of these oils, the dependence of the bacterial metabolic activity from the growth medium, solid or liquid, might influence the microbial growth and survival (Skandamis et al. 2000).
Antimicrobial susceptibility tests with plant extracts using the microdilution plate may have drawbacks such as precipitation of some components in the extract and adherence of some microorganisms to the bottom of the hole making it difficult to analyze (Ostrosky et al. 2008). However, liquid medium was considered the best medium for the evaluation of antimicrobial activity using the natural compounds (Skandamis et al. 2000). Methanol was used to facilitate the dissolution of the extracts in a liquid culture medium and assess its minimum bactericidal activity (data not shown). In the present work, methanol showed no antimicrobial activity against Aeromonas. The lack of antimicrobial activity of methanol had also been found in Gram-negative bacteria (Pinto et al. 2001). Celiktas et al (2007) found low antimicrobial activity of methanol for the genus Staphylococcus and this activity was considered insignificant when compared to the essential oil tested.

\section{CONCLUSION}

The results obtained in the present work scientifically support the use of preparations of $A$. triphylla, traditionally used to treat the bacterial diseases. However, the antibacterial activity was influenced by the extraction conditions.

\section{ACKNOWLEDGEMENTS}

The authors thank Dr. Gilberto Dolejal Zanetti for the identification of the species. This work was supported by PRONEX/FAPERGS-CNPq and CAPES. B. Baldisserotto, A. P. C. Vargas, E. M. M. Flores and J. V. Oliveira were recipient of CNPq fellowships. T.V. Parodi, received $\mathrm{PhD}$ fellowships from Coordenação de Aperfeiçoamento de Pessoal de Nível Superior (CAPES).

\section{REFERENCES}

Adams RP. Identification of essential oil components by gas chromatography / quadrupole mass spectroscopy. 4th ed. Illinois: Allured Publ. Corp.; 2007.

Argyropoulou C, Daferera D, Tarantilis PA, Fasseas C, Polissiou M. Chemical composition of the essential 
oil from leaves of Lippia citriodora H.B.K. (Verbenaceae) at two developmental stages. M. Biol. Syst. and Ecol. 2007; 35: 831-837

Bandoni AL, Lira PDL, Baren CMV, Retta D. Characterization of lemon verbena (Aloysia citriodora Palau) from Argentina by the essential oil J. Ess. Oil Res. 2008; 20: 350-353

Bakkali F, Averbeck S, Averbeck D, Idaomar M. Biological effects of essential oils - A review. Food Chem. Toxicol. 2008; 46: 446-475

Belletti N, Ndagijimana M, Sisto C, Guerzoni ME, Lanciotti R, Gardini F. Evaluation of the antimicrobial activity of citrus essences on Saccharomyces cerevisiae, J. Agric. Food Chem. 2004; 52: 6932-6938

Burt S. Essential oils: Their antibacterial properties and potential applications in foods - A review. Int. J. Food Microbiol. 2004; 94: 223-253

Carnat V, Carnat AP, Fraisse D, Lamaison JL. The aromatic and polyphenolic composition of lemon verbena tea. Fitoterapia. 1999; 70: 44-49

Celiktas OY, Kocabas EEH, Bedir E, Sukan FV, Ozek $\mathrm{T}$, Baser KHC. Antimicrobial activities of methanol extracts and essential oils of Rosmarinus officinalis, depending on location and seasonal variations. Food Chem. 2007; 100: 553-559

Ceylan E, Fung DYC. Antimicrobial activity of spices. J. Rapid Methods Autom. Microbiol. 2004; 12: 1-55

Clermont EG, Wahli T, Frey J, Burr SE. Identification of bacteria from the normal flora of perch, Perca fluviatliis L., and evaluation of their inhibitory potential towards Aeromonas species J. Fish Dis. 2008; 31: 353-359

Crabas N, Marongiu B, Piras A, Pivetta T, Porcedda S. Extraction, separation and isolation of volatiles and dyes from Calendula officinalis L. and Aloysia triphylla (L'Herit.) Britton by supercritical $\mathrm{CO}_{2} \mathrm{~J}$. Ess. Oil Res. 2003; 15: 350-355

Delaquis PJ, Stanich K, Girard B, Mazza G. Antimicrobial activity of individual and mixed fractions of dill, cilantro, coriander and eucalyptus essential oils. Int. J. Food Microbiol. 2002; 74: 101109

Dorman HJ, Deans SG. Antimicrobial agents from plants: antibacterial activity of plant volatile oils. $J$. App. Microbiol. 2000; 88: 308-316

Erasto P, Viljoen AM. Limonene - A review: biosynthetic, ecological and pharmacological relevance. Nat. Product Communicat. 2008; 3: 1193 1202

Fisher K, Phillips CA. J. App. Microbiol. 2006; 101(6): 1232-1240

Geyid A, Abebe D, Debella A, Makonnen Z, Aberra F, Teka F, et al. Screening of some medicinal plants of Ethiopia for their anti-microbial properties and chemical profiles J. Ethnopharmacol. 2005; 97: 421427
Gomes PCS, Ferreira MF, Vicente AMS. Composition of the essential oils from flowers and leaves of vervain (Aloysia triphylla (L'Hérit.) Briton) grown in Portugal J. Ess. Oil Res. 2005; 17: 73-78

Inouye S, Yamaguchi H, Takizawa T. Screening of the antibacterial effects of a variety of essential oils on respiratory tract pathogens, using a modified dilution assay method. J. Infec. Chem. 2001; 7: 251-254

Khajeh M, Yamini Y, Sefidkon F, Bahramifar N. Comparison of essential oil composition of Carum copticum obtained by supercritical carbon dioxide extraction and hydrodistillation methods Food Chem. 2004; 86(4): 587-591

Kim J, Marshall MR, Wei C. Antimicrobial activity of some essential oil components against five foodborne pathogens J. Agric. Food Chem. 1995; 43: 2839-2845

Kim J, Marshall M, Cornell J, Preston J, Wei C Antibacterial activity of carvacrol, citral, and geraniol against Salmonella typhimurium in culture medium and on fish cubes J Food Sci 1995; 60: 1364-1368

Krzyminska S, Kaznowski A, Chodysz M. Aeromonas spp. human isolates induce of murine macrophages Current Microbiol. 2009; 58: 252-257

Lachowicz KJ, Gwyn PJ, Briggs DR, Bienvenu FE, Palmer MV, Mishra V, et al. Characteristics of plants and plant extracts from five varieties of basil (Ocimum basilicum L.) grown in Australia Agric. Food Chem. 1997; 45: 2660-2665

Mann CM, Cox SD, Markham JL. The outer membrane of Pseudomonas aeruginosa NCTC 6749 contributes to its tolerance to the essential oil of Melaleuca alternifolia (tea tree oil). Let. Ap. Microbiol. 200; 30: 294-297

Marongiu B, Piras A, Porcedda S, Tuveri E, Laconi S, Deidda D, et al. Chemical and biological comparisons on supercritical extracts of Tanacetum cinerariifolium (Trevir) Sch. Bip. with three related species of chrysanthemums of Sardinia (Italy) . Nat. Prod. Res. 2009; 7: 190-199

Mazutti M, Beledelli B, Mossi AJ. Caracterização química de extratos de Ocimum Basilicum L. obtidos através de extração com $\mathrm{CO}_{2}$ a altas pressões. Quim. Nova. 2006; 29: 1198-1202

National Committee for Clinical Laboratory Standards (NCCLS): Methods for aerobically, Approved Standard M7 - A6. 6th ed. New York: Wayne; 2003.

National Institute of Standards and Technology. NIST Scientific and Technical Databases. The NIST Mass Spectral Search Program for the NIST/EPA/NIM Mass Spectral Library Version 1.7; 1998.

Oskay M, Tamer AÜ, Ay G, Sari D, Aktas K. Antimicrobial activity of the leaves of Lippia triphylla (L'Her.) O. Kuntze (Verbenaceae) against on bacteria and yeasts. J. Biol. Sci. 2005; 5: 620-622

Ostrosky EA, Mizumoto MK, Lima MEL, Kaneko TM, Nishikawa SO, Freitas BR. Methods for evaluation of the antimicrobial activity and determination of 
Minimum Inhibitory Concentration (MIC) of plant extracts. Braz. J. Pharmacog. 2008; 18: 301-307

Ozturk S, Ercisli S. The chemical composition of essential oil and in vitro antibacterial activities of essential oil and methanol extract of Ziziphora persica Bunge. J. Ethnopharmacol. 2006; 106(3): 372-376

Paniagua C, Rivero O, Anguita J, Naharro G. Pathogenicity factors and virulence for rainbow trout (Salmo gairdeneri) of motile Aeromonas spp. isolated from a river J. Clin. Microbiol. 1999; 28: 350-355

Pascual ME, Slowing K, Carretero E, Sánches MD, Villar A. Lippia: traditional uses, chemistry and pharmacology: a review J. Ethnopharmacol. 2001; 76: 201-214

Pereira CG, Meireles AA. Evaluation of global yield, composition, antioxidant activity and cost of manufacturing of extracts from lemon verbena (Aloysia triphylla (L'Hérit.) Britton) and mango (Mangifera indica L.) leaves, J. Food Process. Eng. 2007; 30: 150-173

Pinto MS, Faria JE, Message D, Cassini STA, Pereira CS, Gioso MM. Effect of green propolis extracts on pathogenic bacteria isolated from milk of cows with mastitis. Braz. J. vet. Res. Anim. Sci. 2001; 38: 278283

Quinn PJ, Carter ME, Markey B, Carter GR. Clinical Veterinary Microbiology. London: P. imprenta; 1994.

Reichling J, Schnitzler P, Suschke U, Saller R. Essential oils of aromatic plants with antibacterial, antifungal, antiviral, and cytotoxic properties - an overview. Fors. Komplem. 2009; 16: 79-90

Rojas LB, Velasco J, Díaz T, Gil RO, Carmona J, Usubillaga A. Chemical composition and antibacterial effects of the essential oil of Aloysia triphylla against genito-urinary pathogens Bol. Latinoamericano $y$ del Caribe de Plantas Medicinales y Aromaticas. 2010; 9(1): 56-62

Romeo FV, Luca S, Piscopo A, Poiana M. Antimicrobial effect of some essential oils. J. Ess. Oil Res. 2008; 20: 373-379

Saavedra MJ, Novais SG, Alves A, Rema P, Tacão M, Correia A, et al. Resistance to $\beta$-lactam antibiotics in Aeromonas hydrophila isolated from rainbow trout (Oncorhynchus mykiss). Inter. Microbiol. 2004; 7: 207-211

Sahena F, Zaidul ISM, Jinap S, Karim AA, Abbas KA, Norulaini NAN, et al. Application of supercritical $\mathrm{CO}_{2}$ in lipid extraction - A review. J. Food Eng. 2009; 95: 240-253

Scalia S, Giuffreda L, Pallado P. Analytical and preparative supercritical fluid extraction of Chamomile flowers and its comparison with conventional methods. J. Pharm. Biom. Anal. 1999; 21: $549-558$

Sikkema J, Weber FJ, Heipieper HJ, De Bont JAM. Cellular toxicity of lipophilic compounds:
Mechanisms, implications, and adaptations. Biocatalasys. 1994; 10: 113-122

Silva CM, Bolzan AA, Mallmann CA, Alves SH, Heinzmann BM. Sesquiterpenoids of Senecio bonariensis Hook et Arn. Rev. Bras. Farmacogn. 2010; 20(1): 87-92

Singh P, Shukla R, Prakash B, Kumar A, Singh S, Mishra PK, et al. Chemical profile, antifungal, antiaflatoxigenic and antioxidant activity of Citrus maxima Burm. and Citrus sinensis (L.) Osbeck essential oils and their cyclic monoterpene, DL limonene. Food and Chem. Toxicol. 2010; 48: 17341740

Singh N, Singh RK, Bhunia AK, Stroshine RL. Efficacy of chlorine dioxide, ozone and thyme essential oil or a sequential washing in killing E. coli O157:H7 on lettuce and baby carrots. Lebensm.-Wiss. u.-Technol. 2002; 35: 720-729

Svodoba KP, Greenaway RI. Investigation of volatile oil glands of Satureja hortensis L. (summer savory) and phytochemical comparison of different varieties. Int. J. Arom. 2003; 13: 196-202

Svodoba K, Brooher JD, Zrustova J. Antibacterial and antioxidant of essential oils: their potential applications in the food industries. Acta Hort. 2006; 709: 35-43

Skandamis P, Tsigarida E, Nychas GJE. Ecophysiological atributes of Salmonella typhimurium in liquid culture and within gelatin gel with or without the addition of oregano essential oil. World J. Microbiol. Biotechnol. 2000; 16: 31-35

Sköld M, Karlberg A-T, Matura M, Börje A. The fragrance chemical $\beta$-caryophyllene - air oxidation and skin sensitization. Food and Chemical Toxicol. 2006; 44: 538-545

Tajkarimi MM, Ibrahim SA, Cliver DO. Antimicrobial herb and spice compounds in food. Food Control 2010; 21: 1199-1218

Valentão P, Andrade PB, Areias F, Ferreres F, Seabra RMJ. Analysis of vervain flavonoids by HPLC/diode array detector method. Agric. Food Chem. 1999; 47: $4579-4582$

Wenqiang G, Shufen L, Ruixiang Y, Shaokun T, Can Q. Comparison of essential oils of clove buds extracted with supercritical carbon dioxide and other three traditional extraction methods. Food Chem. 2007; 101: 1558-1564

Yoon WJ, Lee NH, Hyun CG. Limonene suppress lipopolysaccharide-induced production of nitric oxide, prostaglandin E2, and pro-inflammatory cytokines in RAW 264.7 macorphages. J. Oleo Sci. 2010; 59(8): 415-421 